\title{
STUDIES ON THE REACTIVITY OF SKIN VESSELS TO EXTREME COLD
}

\author{
PART II. FACTORS GOVERING THE INDIVIDUAL \\ DIFFERENCE OF THE REACTIVITY, OR THE \\ RESISTANCE AGAINST FROST-BITE.
}

\author{
HISATO YOSHIMURA AND TOSHIYUKI IIDA* \\ Institute of Physiology, Kyoto Prefectural Medical College, Kyoto, and \\ Institute of Physiology, Hyogo Prefectual Medical College, Kobe.
}

It was previously reported that the temperature reaction to cold appearing on the peripheral parts of limbs varied considerably in different subjects and that this individual variation was caused by that of reactivity of cutaneous vessels and was closely correlated with the variance of the resistance against frost-bite (1). In the first part of this study (2), the authors devised a practical method to estimate the reactivity, and expressed it in a numerical value which was named "resistance index of frost-bite." In the present part, the authors undertook to clarify causes of the individual differences of the reactivity by measuring the resistance index. In this paper, however, the index is called the reaction index. So far as we are aware, there is no detailed study on this problem in part records except Takahashi's (3) in which the effect of training with cold water on the response of human feet was studied.

METHODS

To estimate the temperature reaction to cold, the left middle finger was examined in so far as not otherwise required, and by measuring the temperature change of the finger skin in ice-water, the reaction index was calculated as usual and corrected to that at the standard room temperature of $20^{\circ} \mathrm{C}$. $(c f$. Part I (2)).

As factors affecting the individual differences of the reactivity, age, sex, native land, racial specificity and grade of training to cold were at first adopted to investigation, and then influences of some internal factors of individual constitution such as the tonus of autonomic nerves were studied. Details of experimental methods are described in each corresponding section.

\section{EXPERIMENTAL RESULTS}

Effects of age and sexual differences. The temperature reaction in ice-water was examined on about 100 Chinese coolies from 15 to 74 years old and on

Received for publication October 6, 1951.

*吉村寿人, 飯田敏行 


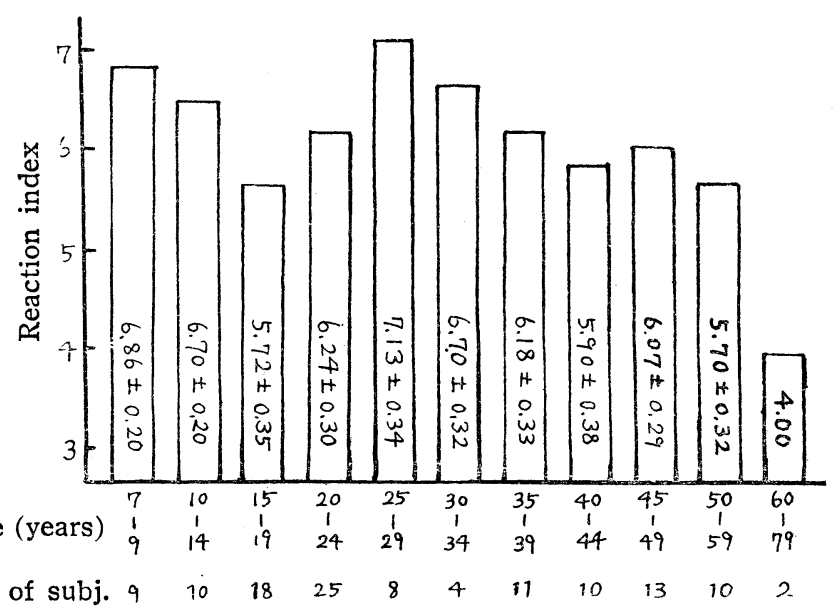

Fig. 1. Ages and reactivity to cold.

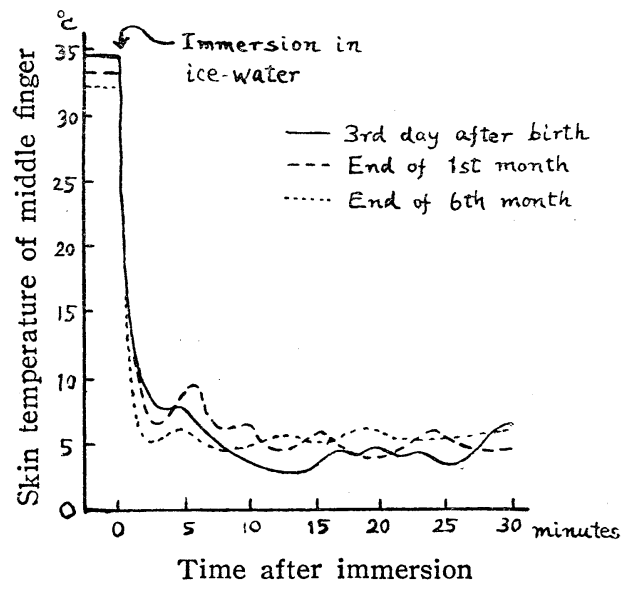

Fig. 2. Temperature reaction to cold observed on a baby.

Table 1. Sexual difference of reaction index estimated on Orochons

\begin{tabular}{c|c|c|c|c}
\hline & \multicolumn{2}{|c|}{ Male } & \multicolumn{2}{c}{ Female } \\
\cline { 2 - 5 } (years) & $\begin{array}{c}\text { Nos. of } \\
\text { subj. }\end{array}$ & $\begin{array}{c}\text { Reaction } \\
\text { index }\end{array}$ & $\begin{array}{c}\text { Nos. of } \\
\text { subj. }\end{array}$ & $\begin{array}{c}\text { Reaction } \\
\text { index }\end{array}$ \\
\hline $10-14$ & 5 & 7.20 & 2 & 7.50 \\
$15-19$ & 4 & 8.00 & 1 & 9.00 \\
$20-29$ & 3 & 8.66 & 7 & 7.59 \\
$30-39$ & 4 & 8.00 & 3 & 7.33 \\
\hline Total & 16 & $7.87 \pm 0.14$ & 13 & $7.61 \pm 0.12$ \\
\hline
\end{tabular}

Remark: Values after \pm is the probable error of the mean. It is the same in all the following tables. about 20 Chinese pupils of 7 to 14 years. The results obtained were averaged on groups of every 5 years, and changes of the reaction index with progress of age were observed as is seen in fig. 1 . The maximum reactivity was found at the ages of 25 to 29 years, and, as the age became younger or older, the reactivity generally decreased more and more, except that in childhood it was higher than in puberty. Thus the general aspect of change of reactivity with age was similar to that of the other phyisological functions.

Though detailed studies could not be attained on children below 6 years of age, some observations were carried out on a baby. As is seen in fig. 2 , the reaction was detected even on the 3rd day after birth, and it increased rapidly with the lapse of days until at last it was nearly fixed after a month or so.

As to sexual difference of the reactivity, only an outlining aspect was obtained from the observation on Orochon subjects, which are described in table 1 . The reactivity of 
the female subject was a little lower than the male's in adult age, while they were nearly the same with each other in childhood ( $c f$. the footnote of table 3 ).

Difference owing to native countries. On 134 Japanese students of Medical College of Chamuszu (18-28 years old) and 60 Chinese coolies (20-45 years old), the reaction index was measured, and the results obtained were averaged in three or two groups respectively according to the climates of their native countries where the subjects lived over half their age. Namely, the Japanese were divided into three groups of warm (Chugoku, Shikoku, Kyushu), moderate (Kanto, Tokai, Kinki, San-in) and cold regions (Hokkaido, Tohoku, Hokuriku), while the Chinese into two groups of Shan-tung (warm) and North Manchuria (cold).

Table 2. Native countries and temperature reaction to cold

\begin{tabular}{|c|c|c|c|}
\hline Subjects & Native country & Nos. of subj. & Reaction index \\
\hline $\begin{array}{l}\text { Japanese } \\
\text { students } \\
(18-28 \text { y.) }\end{array}$ & $\begin{array}{l}\text { Cold region } \\
\text { Moderate region } \\
\text { Warm region }\end{array}$ & $\begin{array}{l}65 \\
33 \\
36\end{array}$ & $\begin{array}{l}6.08 \pm 0.13 \\
6.18 \pm 0.12 \\
5.47 \pm 0.16\end{array}$ \\
\hline $\begin{array}{l}\text { Chinese } \\
\text { coolies } \\
(20-45 \text { y.) }\end{array}$ & $\begin{array}{l}\text { Shar-tung } \\
\text { Manchuria }\end{array}$ & $\begin{array}{l}27 \\
33\end{array}$ & $\begin{array}{l}5.49 \pm 0.23 \\
6.94 \pm 0.20\end{array}$ \\
\hline
\end{tabular}

As can be seen from table 2, the mean reaction index of Japanese students of the warm region was significantly lower than in those of the other regions, while the difference between cold and moderate regions was not statistically significant. A similar significant difference was also found between Chinese indices of the cold and warm regions. Thus the subjects brought up in cold countries exhibited more sensitive temperature reaction to cold than those of warm native countries. This may probably be due to that former had been trained to cold by chilly living conditions.

Racial difference and its relation with training effects due to cold climate. To find out the racial difference of temperature reaction to cold, the reaction index was measured on the Japanese and the Chinese living in Manchuria, and the Manchurian Mongols and the Orochons native-born there, of which the last mentioned is well known as a nomadic tribe in the Khin-gan Mountains. As is seen in the right column of table 3 , the mean index of the Orochons was the

Table 3. Racial differences of reaction index

\begin{tabular}{|c|c|c|c|c|c|c|c|c|c|}
\hline \multirow{2}{*}{ Nations } & \multicolumn{2}{|c|}{$\begin{array}{l}\text { Childhood } \\
\text { (8-14 years) }\end{array}$} & \multicolumn{2}{|c|}{$\begin{array}{c}\text { Youth } \\
\text { (15-19 years) }\end{array}$} & \multicolumn{2}{|c|}{$\begin{array}{c}\text { Adult } \\
\text { (20-28 years) }\end{array}$} & \multicolumn{3}{|c|}{$\begin{array}{l}\text { Total } \\
\text { average }\end{array}$} \\
\hline & $\begin{array}{l}\text { Nos. of } \\
\text { subj. }\end{array}$ & $\begin{array}{c}\text { Reaction } \\
\text { index }\end{array}$ & $\begin{array}{l}\text { Nos. of } \\
\text { subj. }\end{array}$ & $\begin{array}{c}\text { Reaction } \\
\text { index }\end{array}$ & $\begin{array}{l}\text { Nos. of } \\
\text { subj. }\end{array}$ & $\begin{array}{c}\text { Reaction } \\
\text { index }\end{array}$ & $\begin{array}{c}\text { Ages } \\
\text { (years) }\end{array}$ & $\begin{array}{l}\text { Nos. of } \\
\text { subj. }\end{array}$ & $\begin{array}{c}\text { Reaction } \\
\text { index }\end{array}$ \\
\hline $\begin{array}{l}\text { Japanese } \\
\text { Chinese } \\
\text { Mongol } \\
\text { Orochon }\end{array}$ & $\begin{array}{r}74 \\
17 \\
22 \\
5\end{array}$ & $\begin{array}{c}6.39 \pm 0.11 \\
6.77 \pm 0.15 \\
6.64 \pm 0.18 \\
7.20\end{array}$ & $\begin{array}{r}156 \\
21 \\
28 \\
4\end{array}$ & $\begin{array}{c}5.76 \pm 0.09 \\
6.19 \pm 0.29 \\
6.14 \pm 0.17 \\
8.00\end{array}$ & $\begin{array}{r}137 \\
14 \\
22 \\
3\end{array}$ & $\begin{array}{c}5.80 \pm 0.09 \\
6.71 \pm 0.18 \\
6.50 \pm 0.16 \\
8.66\end{array}$ & $\begin{array}{r}8-27 \\
8-28 \\
8-28 \\
10-57\end{array}$ & $\begin{array}{r}367 \\
52 \\
72 \\
19\end{array}$ & $\begin{array}{l}5.90 \pm 0.05 \\
6.52 \pm 0.13 \\
6.49 \pm 0.10 \\
7.68 \pm 0.20\end{array}$ \\
\hline
\end{tabular}

Footnote: Mean reaction index of 19 Chinese girls of $15-19$ years was $6.67 \pm 0.26$, of which difference from the boys' value was statistically insignificant. 
greatest among all, and that of the Japanese the smallest, while those of the Mongols and the Chinese were the middle, showing no significant difference from each other. As these mean values implied errors due to difference of age, comparisons were made among the values averaged on the same age of respective nations, which are described in left three columns of the table. While no significant racial differences were found in childhood and by the gross in the age of youth, it was shown, in adult age, that the mean reaction index of the Japanese was distinctly lower than the indices of the other nations. The difference between the Chinese and the Mongol adults was statistically insignificant. Though statistical comparison was omitted by reason of not enough number of observations, the Orochon index was the highest among all in every age.

In short, the racial difference came to be manifest as the age advanced, while it was insignificant in the age of childhood. The above results strongly suggest that the reactivity of cutaneous vessels to cold, or the resistance to frostbite innately bears no racial specificity, (at least none among yellow races), but is readily affected by cold living condition. This is the reason why the reactivities of the native adults in cold countries, such as the Mongols, the Orochons and the Chinese born in Manchuria, are superior to that of the Japanese who came there in recent years. The fact also suggests that training intensely raises the resistance to frost-bite. An exceptionally high reactivity of Orochon children may also be due to their special habitude of nomadic out-door life since birth which trained them severely and continuously.

Effects of training to cold. According to Takahashi.(3), temperature reaction of toes increased considerably when the leg of a subject was trained in cold water, and he suggested that the training effect might be eminent on young subjects. Similarly to this experiment, the authors attempted to train Japanese boys and soldiers by immersing their feet in ice-water every day for a month. To compare effects of varied grades of training, both young and adult subjects were divided respectively into three groups of about the same number (about 10), and the first group was trained daily for 15 minutes, and the second for 30 minutes, while the third was a control group and not trained throughout the experimental period. During the immersion in ice-water, the skin temperature of the big toe was measured every minute after immersion with thermo-junction attached on its back as usual (2). Judging from the temperature-time curve thus obtained and subjective pain experienced during immersion, the effect of training was estimated. The results obtained are shown in table 4, where changes of three principal characteristics of temperature reaction after a month's training are described. Numerals of thick type represent statistically significant changes of characteristics. As is seen there, daily immersion of 15 minutes accelerated markedly the temperature reaction of boys, while it had no significant effect on adults, and immersion of 30 minutes increased the reaction slightly on both groups. Subjective pain in ice-water was also lessened on the trained groups, while control groups showed no significant changes in all respects after the lapse of a month. Thus the training surely accelerated the temperature reaction to cold, though slightly on adults. When the training was not severe 
Table 4. Effects of training feet by immersion in ice-water (in summer)

\begin{tabular}{|c|c|c|c|c|c|c|}
\hline \multirow{2}{*}{ Groups } & \multirow{2}{*}{$\begin{array}{l}\text { Duration } \\
\text { of daily } \\
\text { immersion }\end{array}$} & \multirow{2}{*}{$\begin{array}{c}\text { Characteristics } \\
\text { of reaction } \\
\text { curve }\end{array}$} & \multicolumn{2}{|c|}{ Boys (16-17 years) } & \multicolumn{2}{|c|}{ Adults (22-23 years) } \\
\hline & & & $\begin{array}{l}\text { Before } \\
\text { training }\end{array}$ & $\begin{array}{l}\text { Change after } \\
1 \text { month }\end{array}$ & $\begin{array}{c}\text { Before } \\
\text { training }\end{array}$ & $\begin{array}{c}\text { Change after } \\
1 \text { month }\end{array}$ \\
\hline I & $\begin{array}{c}15 \\
\text { minutes }\end{array}$ & $\begin{array}{l}\text { M.S.T. }\left({ }^{\circ} \mathrm{C}\right) \\
\text { T.F.R. }\left({ }^{\circ} \mathrm{C}\right) \\
\text { T.T.R. }(\mathrm{m})\end{array}$ & $\begin{array}{r}4.16 \\
2.50 \\
15.50\end{array}$ & $\begin{array}{l}+2.07 \\
+2.04 \\
+7.50\end{array}$ & $\begin{array}{r}4.02 \\
3.04 \\
12.90\end{array}$ & $\begin{array}{l}+0.66 \\
+0.24 \\
-0.50\end{array}$ \\
\hline II & $\begin{array}{c}30 \\
\text { minutes }\end{array}$ & $\begin{array}{l}\text { M.S.T. }\left({ }^{\circ} \mathrm{C}\right) \\
\text { T.F.R. }\left({ }^{\circ} \mathrm{C}\right) \\
\text { T.T.R. }(\mathrm{m})\end{array}$ & $\begin{array}{r}5.33 \\
2.89 \\
14.10\end{array}$ & $\begin{array}{l}+0.61 \\
+1.49 \\
+4.30\end{array}$ & $\begin{array}{r}4.95 \\
3.02 \\
12.90\end{array}$ & $\begin{array}{l}+1.38 \\
+0.93 \\
-0.10\end{array}$ \\
\hline III & control & $\begin{array}{l}\text { M.S.T. }\left({ }^{\circ} \mathrm{C}\right) \\
\text { T.F.R. }\left({ }^{\circ} \mathrm{C}\right) \\
\text { T.T.R. }(\mathrm{m})\end{array}$ & $\begin{array}{r}5.85 \\
3.20 \\
14.50\end{array}$ & $\begin{array}{l}+0.58 \\
+0.65 \\
+4.20\end{array}$ & $\begin{array}{r}5.70 \\
3.47 \\
10.70\end{array}$ & $\begin{array}{l}-0.32 \\
-0.23 \\
+0.20\end{array}$ \\
\hline
\end{tabular}

Remarks : M.S.T. : Mean skin temperature of the big toe during immersion.

T.F.R.: The skin temperature at its first rise after immersoin.

T.T.R.: Time in minutes for the first temperature rise after immersion.

Values of bold-face type show statistically significant change due to training.

enough, no significant effect could be expected on adults, while boys showed rather remarkable acceleration of the reaction. For these, it seems probable that training is more effective on young subjects than on adults, and over training may rather harm its benefit on the former.

These methods of immersion in ice-water was not recommendable as a means of training, because the subjects complained more or less pain on feet, and some of them suffered from stomach ache or cerebral anemia during the immersion. So the authors tried to test effects of more moderate and practical methods of training. The following investigations were among those tests.

In Chiamuszu Medical College, free gymnastics of 20 minutes or so were imposed on all students every moring throughout the year. During the work, they stripped the upper halves of their bodies naked for the sake of training. The authors examined their reaction indices shortly after the commencement of a new school year, i.e. in June, when the second year class had experienced the training during a severe cold winter, while the first year class, having just come to Manchuria, had no experience. The results are summarised in table 5. Though the mean index of the second year class was somewhat higher than that of the first year class, the difference was not statistically significant. If this had been commenced in younger age and continued longer, the effect should probably have been more remarkable in view of the facts mentioned above.

A similar test was carried

Table 5. Effects of experience of cold winter in Manchuria

\begin{tabular}{|c|c|c|c|}
\hline Subjects & Groups & $\begin{array}{c}\text { Nos. of } \\
\text { subj. }\end{array}$ & $\begin{array}{l}\text { Reaction } \\
\text { index }\end{array}$ \\
\hline \multirow{2}{*}{$\begin{array}{c}\text { Medical } \\
\text { students } \\
(18-28 \text { y.) }\end{array}$} & 1st year class & 74 & $5.89 \pm 0.10$ \\
\hline & 2nd year class & 60 & $6.17 \pm 0.16$ \\
\hline \multirow{3}{*}{$\begin{array}{l}\text { Japanese } \\
\text { soldiers } \\
\text { in Manch. } \\
(20-28 \text { y.) }\end{array}$} & 1st year in $M$. & 39 & $6.15 \pm 0.18$ \\
\hline & 2nd year in $M$. & 42 & $5.74 \pm 0.16$ \\
\hline & 3rd year in $M$. & 56 & $5.55 \pm 0.12$ \\
\hline
\end{tabular}


out on Japanese soldiers stationed in North Manchuria. They were grouped into three, of which the first one experienced no winter in Manchuria, while the second and third ones had experienced one and two winter respectively. Any special training was not imposed in this case. As is seen in table 5 , mean indices of the second and third groups were not greater than the first.

In short, a severe training to cold has a certain effect to raise the reactivity in relatively short period, especially on young subiects, but, for its practical operation, it is advisable to find some moderate and effective method.

Relation with tonus of autonomic nerves. To study on interrelation between the reactivity of finger vessels to cold and constitutional differences of individuals having common age, sex, nationality and life history, the authors estimated pharmacodynamic tonus of autonomic nervous system as well as the reaction index on 26 adult male Japanese. To estimate the nervous tone, familiar adrenaline and pilocarpine tests were adopted. Either when the blood pressure rose by over $30 \mathrm{~mm}$. Hg in 30 minutes after a subcutaneous injection of 1 cc. of 0.1 per cent adrenaline, or when the pulse rate increased by over 30 per minute after the injection, the subject was judged as sympathicotonia. When the rate of salivation after the injection of 1 cc. pilocarpine (1\%) was accelerated over $150 \mathrm{cc}$. per hour, or when the blood pressure fell after the injection of adrenaline, he was designated as vagotonia. The subjects belonging to neither of these were judged as normal. The subjects thus examined were divided into two groups, half and half, according to the magnitude of their reaction indices, of which the mean value was $6.37 \pm 0.60$ in the highly reactive group, and $4.77 \pm 0.43$ in the low. In each group, numbers of vagotonia, vagosympathicotonia etc. were enumerated, as is seen in table 6 . There could not

Table 6. Temperature reaction and tone of autonomic nerves

\begin{tabular}{l|c|c}
\hline \hline & $\begin{array}{c}\text { Group of } \\
\text { high reactivity }\end{array}$ & $\begin{array}{c}\text { Group of } \\
\text { low reactivity }\end{array}$ \\
\hline Reaction index & $6.37 \pm 0.60$ & $4.77 \pm 0.43$ \\
\hline Vago-sympathicotonia & 3 & 8 \\
Vagotonia & 8 & 4 \\
Normal subjects & 2 & 1 \\
\hline Total number & 13 & 13 \\
\hline
\end{tabular}

be found a purely sympathicotonic one. Recomposing a four fold table from the results presented, and examining by $\chi^{2}$-test, it was proved that the frequency of vago-sympathicotonia was significantly higher in the low reactive group than in the high, while the frequency of vagotonia showed no significant difference between the two. Therefore it may be concluded that the tonus of sympathetic nerve is more frequently high in the case of low reactivity. As the reactivity here discussed is concerned to vasodilation of skin vessels (see below), it should naturally be lessened when the tonus of sympathetic nerve, i.e. vasoconstrictor, is raised. 


\section{DISCUSSION}

According to Lewis (4), Grant and Bland (5), the temperature reaction mentioned above is a vasodilating axon reflex of arterio-venous anastomosis on the peripheral parts of four limbs. Iida (6) proved that not only arterio-venous anastomosis but also local capillaries and even small arteries may play a rôle in the reaction, and its nervous control is mainly displayed by cutaneous nerve. It was found also that the subject having a high reaction index showed a remarkable red reaction by histamine or heat application, and vice versa (1). Since the red reaction is an axon reflex through cutaneous vasodilator as was proved by Lewis (7), the above mentioned fact of parallelism between the two sorts of reactiviy is presumed to authorize Lewis' theory on the temperature reaction (4), which assumed $\mathrm{H}$-substance produced in the skin by its stimulation as a starter of the reflex. For these points of view, it may be approved that the individual difference of the reaction are mainly due to difference of the nervous control (the first factor), anatomical constitution of finger and toe (the second factor), and other physiological properties of the skin (the third factor).

Among these, an example of individual difference of the nervous control or nervous activity was already described in the above section of autonomic nervous tonus, and another one will be discussed in the next report.

Concerning a rôle of anatomical constitution, the following fact will be quoted. Table 7 shows the characteristics of temperature reaction appeared on various parts of the left hand immersed in ice-water for 30 minutes. Figures in the table are the mean values of about 50 adult males. Here is seen that the reaction is the most vigorous on the thumb and the least on the fifth finger.

Table 7. Temperature reaction on various parts on the left hand and its fingers' backs. (Mean of 50 subjects in the room of $20^{\circ} \mathrm{C}$ )

\begin{tabular}{l|c|c|c|c}
\hline \hline Site of observ. & M.S.T. $\left({ }^{\circ} \mathrm{C}\right)$ & T.F.R. $\left({ }^{\circ} \mathrm{C}\right)$ & T.T.R. $(\mathrm{m})$ & A.F. $\left({ }^{\circ} \mathrm{C}\right)$ \\
\hline Palm of hand & $8.08 \pm 0.26$ & $7.97 \pm 0.33$ & $12.21 \pm 0.70$ & $2.38 \pm 0.18$ \\
Back of hand & $4.67 \pm 0.17$ & $3.50 \pm 0.16$ & $15.34 \pm 0.62$ & $2.28 \pm 0.16$ \\
1st finger & $7.18 \pm 0.24$ & $2.54 \pm 0.16$ & $8.97 \pm 0.21$ & $6.04 \pm 0.29$ \\
3rd finger & $4.93 \pm 0.24$ & $1.82 \pm 0.12$ & $9.89 \pm 0.25$ & $5.36 \pm 0.30$ \\
5th finger & $3.78 \pm 0.19$ & $1.79 \pm 0.13$ & $9.77 \pm 0.26$ & $4.45 \pm 0.18$ \\
\hline
\end{tabular}

Remarks : A.F.: Represents the amplitude of temperature reaction, i.e. difference between the temperature at its first rise and that at the maximum of this rise.

As to other notations, refer to table 4 .

On the paim and the back of the hand, the reaction outbreaks some minutes later than on the fingers. The temperature of the palm is, however, always the highest of all, while the amplitude of temperature fluctuation is smaller than those of the fingers. (Significant differences can hardly be found between the right and left fingers as well as hands.) It is interesting that these regional differences have intimate relations between regional susceptibilities to frostbite reported in military histories (8). These regional differences of the reaction is supposed to be due to differences of anatomical constitution, especially the density of blood vessels, since the nervous control is, in this case, common to all 
parts, as is partly proved by the fact of synchronous outbreak of the reaction on all fingers (9). The time lag of reaciton of the hand from the finger's probably owes to too great anatomical disparities between the two.

Concerning there third factor of individual differences, it is rather better to say that there remains another factor which belongs to neither of the above mentioned two, because the reactivity shows some individual difference even among the subjects who are of the same age, sex and race, and whose physical constitutions and tonus of automomic nervous system are apparently alike to one another. This factor is probably connected with some properties of the skin such as the ability to produce $\mathrm{H}$-substance by a cutaneous stimulus, because the individual difference of the temperature reaction is highly correlated with that of the cutaneous reactivity to histamine or heat locally applied, as already cited.

The above mentioned theory on the cause of individual difference is useful to explain the experimental results obtained in the present investigation. First, as to the change of reactivity accompanied with the lapse of age, changes of topographical or histological constitution of extremities and of nervous control may be its principal causes. That is, the reaction found a few days after birth may arise by minute vessels other than arterio-venous anastomosis, which is believed lacking in the new-born (5), and thereafter it may become remarkable as the arterio-venous anastomosis and also the reflex mechanism develop. The high reactivity maintained in childhood is probably due to abundance of blood vessels and the temporary decrease found in puberty may be due to rapid development of parenchyme and to discordant nervous control. After the reactivity is restored by the completion of development in the adult, it follows the general course of physiological functions accompanied with the progress of age.

Secondly, the sexual differenece is probably due mainly to anatomical difference, as was previously proved that the reaction was lessened when subcutaneous fat of a finger was thickened (1).

As to influences of native lands and racial specificity, their essential factor is presumed to be the effect of training to cold. Thus the effect of training will be discussed lastly as follows :

Since it is a biological law that working organ develops well, and since it was proved already by E. R. and E. L. Clarks (10) that new arterio-venous anastomosis may be regenerated by some adequate stimuli, blood vessels and local nervous control may probably develop in the tissue trained, and thus the reactivity increases as has been proved in previous sections. Development of the tissues being generally more considerable in young subjects than adults, it is probable that the training effect on the former is more marked. So far as the training is adequately severe and is continued from childhood, it may raise the reactivity up to nearly the highest level of the reaction index as is shown by data of the Orochons ( $c f$. table 3 ), thus making up such a distinguished constitution resistant against frost-bite as theirs.

SUMMARY

Factors governing individual differences of temperature reaction to cold 
found by Lewis were studied by estimating reaction index devised in the first part of this study. Main results obtained are as follows:

1. The reaction was found even a few days after birth and developed rapid1y with lapse of days. The high reactivity in childhood was lessened in puberty and again it rose in young adult, after which it decreased gradually with the progress of age.

2. A female adult seemed to show a little lower reactivity than a male.

3. Native countries and racial specificity were proved to have an intimate relation with the reactivity, and a main factor of the influences was deduced to be the effect of training to cold.

4. The Orochons were found to have the highest reactivity among all nations in Manchuria, and thus protecting themselves from frost-bite, adapted to their nomadic life in a cold country. The reactivity of Japanese adults recently came to Manchuria was the lowest of all the natives, while that of Japanese children was about the same with those of the native (the Mongols and the Chinese) children.

5. A validity of training effect reported by Takahashi was ascertained, and it was proved that the effect was more remarkable on the youth than on the adult.

6. Subjects of low reactivity were proved to show frequently high sympathetic tonus. Thus the tonus of autonomic nervous system had an intimate bearing with the reactivity.

7. Main internal factors causing individual differences of the reaction were presumed to be differences of the following three: the morphological constitution, especially of blood vessels, the nervous control (activities) and other physiological properties of the skin. The experimental results mentioned above were explained from this point of view.

\section{REFERENCES}

1. IIDA, T. J. Physiol. Soc. Jap. 11:73, 1949 (Japanese).

2. Yoshimura, H. AND T. IIDA, Jap. J. Physiol. $1: 147,1950$.

3. TAKAhAShI, S. J. Physiol. Soc. Jap. 8: 461, 1943 (Japanese).

4. LEWIS, T. Heart 15: 177, 1930.

5. GRANT. R. T. AND E. F. BLAND, Heart $15: 385,1931$.

6. IIDA, T. J. Physiol. Soc. Jap. 11: 79, 1949 (Japanese).

7. LEwIS, T. The Blood Vessels of the Human Skin and their Responses. London: 1927.

8. IKEI, S. J. Milit. Med. Assoc. No. 305 : 1119, 1938 (Japanese).

9. IIDA, T. J. Physiol. Soc. Jap. (will be published in Vol. 13, 1951).

10. Clark, E. R. ANd E. L. Clark, Amer. J. Anat. 55 : 407, 1939.

(A part of this report was read before the 21st annual meeting of Japanese Physiol. Soc. (1942)) 